\title{
The world through a lens: a history of the Royal Society of London, and the discovery of the red blood cell
}

\author{
Kristian C. Becker
}

Published online: 6 October 2010

(C) Springer Science+Business Media, LLC 2010

At 3 a.m. on September 3, 1666, Samuel Pepys, Secretary of the British Navy and Royal Society member, was awoken by his maid and told about a disturbance outside. Looking east from his bed room window Pepys saw a redorange light glowing through the darkness. The great fire of London had begun. Pepys went back to bed.

Beginning in the bakery of Thomas Farynor, baker to King Charles II, the fire quickly spread through the building, and then the block, aided by a strong autumn wind. From its source the fire progressed rapidly westward among the densely packed houses and government offices made of mostly wood and tar. In his diary Pepys said of the fire, "it made me weep to see it. The churches, houses, and all on fire and flaming at once; and a horrid noise the flames made, and the cracking of houses at their ruins." [1]

Four days later, as the fire began to die, and firefighters were able to halt its progression into the more sparsely populated suburbs, an accurate assessment of the damage was made. By the end of the fourth day 13,200 houses, 87 churches including St. Paul's Cathedral, one of the oldest and most venerated structures in England, 44 professional guildhalls, The Custom House, and The Royal Exchange had all been reduced to ash and rubble. Although official records account for only a handful of deaths due to the fire, as many as 70,000 of the cities 80,000 people were displaced because of it.

But with tragedy may come opportunity. Following the destruction of London, which had grown without organization during its first 1000 years, Charles II was now able to rebuild the city as he saw fit. Through the Rebuilding

K. C. Becker $(\bowtie)$

Duke Clinical Research Institute, Duke University Medical

Center, 2400 Pratt St, Durham, NC 27705, USA

e-mail: Kristiancdbecker@gmail.com
Acts of 1667 and 1670, Charles enacted new laws to regulate the reconstruction effort. Through these acts he hoped to improve the city's organization, “...to the end that great and outrageous fires may be prevented." [2] The Act of 1667 established exact dimensions for the length and height of new houses, to prevent overcrowding, which had significantly contributed to the speed at which the fire had spread. Secondly, the Acts stated that houses could no longer be built from just wood, but must have brick or stone exteriors. Furthermore, all alleys and main streets were widened; sewers were expanded and placed beneath the streets to improve sanitation and living conditions, and all businesses "judged noisome or perilous in respect of fire" [2] were moved away from residential districts. The 1670 Act dealt mostly with the reconstruction of communal buildings, specifically detailing the location and design of parish churches, governmental buildings and the new St. Paul's Cathedral. Combined, these acts painted a new vision for the future development of London.

The man, "appointed surveyor-general and principle architect for rebuilding the whole city" [3] was the engineer, astronomer, and founding member of the Royal Society, Sir Christopher Wren. Wren, who in 1666 had only recently been appointed The Chief Surveyor of the King's Works, was asked to transform the charred remains of downtown London into a modern, sanitary, and organized European capital. Charles II also put Wren in charge of clearing all debris, planning and overseeing the construction of several prominent governmental buildings, and the reestablishment of 51 parish churches. ${ }^{1}$ Two days after the fire, a sleep deprived Wren submitted an entirely original grid design for the streets of London. A short time

\footnotetext{
${ }^{1}$ With the city's reconstruction came a redistribution of its parishes, reducing the number from 87 to 51 .
} 
after, he submitted a design for the new St. Paul's Cathedral. A short time after that, he submitted new designs for the parish churches. It was clear that Wren was capable of fulfilling the King's requests.

In order to begin the cleanup and reconstruction, Wren needed to determine the exact dimension of each street and every alley in the city. To complete this task, Wren appointed several men to survey the damage and measure, as accurately as possible, the length and width of London. He placed his faith in his colleague and friend from Oxford University graduate, Robert Hooke. The collaboration of Hooke and Wren began while at university, and was cultivated during the meetings of The Royal Society, which had begun in London in 1661. Wren, during his years as a professor of astronomy, often turned to Hooke for guidance regarding his research or the logistics of an experiment. Hooke in turn would seek out the opinion and creative insight he felt that only Wren could provide. While Wren dreamt of grand cathedrals, Hooke, as a professor of mathematics, thought of measurements, mechanics, and the gritty details which would be required to reconstruct the city.

Because of the integral role Hooke and Wren played in the reconstruction of London, the pair had effectively transformed the city's renewal into an experiment conducted by The Royal Society. Officially established as The Royal Society of London for the Improvement of Natural Knowledge, The Royal Society began as nothing more than a series of lectures and discussions conducted within Christopher Wren's apartment. Although it received its royal charter from Charles II in 1663, the Society did not come to prominence until the early 1670s, in large part due to the work of its founding members Christopher Wren, Robert Hooke, Robert Boyle and Isaac Newton. The preamble to the Royal Society's charter states that as an academic institution its members wished to, "Prosecute effectively the Advancement of Natural Experimental Philosophy, especially those parts of it which concern the increase of Commerce, by the addition of useful inventions, tending to the Ease, Profit or Health of our Subjects." [4] In order to impart a sense of scholarly rigor into the newly formed society and promote the field of Natural Philosophy, Robert Hooke was appointed the first official Curator of Experiments. Through this position Hooke came in contact with many new pieces of equipment, with the most notable being the microscope, an instrument which would change the course of science and medicine.

The discovery of red blood cells, as well as the other components of blood, began in earnest with the invention and development of the microscope. Like few inventions before it, the microscope revealed to its creators a completely new universe, teeming with life. And to their benefit, the members of the Royal Society realized its scientific potential. Christopher Wren was one of the first to use the microscope as a tool for discovery, but as his attention span was notoriously short, he quickly passed on his equipment to Robert Hooke. After spending the years of 1663 and 1664 making observations, Hooke published his book Micrographia or Some Physiological Descriptions of Minute Bodies made by Magnifying Glasses with Observations and Inquiries thereupon, or more simply Micrographia in 1665. In the preface to his opus, Hooke specifically recognized the contributions made by The Royal Society and those of his friend and colleague Christopher Wren in particular. Hooke remarked that at first he was reluctant to use the microscope for biological observations, "because I was to follow the footsteps of so eminent a person as Dr. Wren who was the first that attempted any thing of this nature." [5] But despite Hooke's initial hesitation, Micrographia was an instant success among both natural philosophers and the public. In addition to the beauty of its illustrations, Hooke had aspired to be an artist in his youth, the text contained an exacting level of observation and specificity. And it is because of its unique synthesis of both artistic and academic detail that Micrographia virtually created the field of microscopy.

To accompany the multitude of original observations he had made, Hooke had to create new terminology to describe them. Through his detailing of the structure of cork, Hooke coined the term "cell", likening the rigid shape of the plant's cells to the dormitories of Anglican monks. After its success in England, Micrographia quickly gained recognition in continental Europe where it was translated, read and discussed among royalty, academics, and the educated middle class. Dutch diplomat Constanijn Huygens, secretary to the Prince of Orange and father of the great mathematician Christiaan Huygens, wrote to Hooke personally to congratulate him on his book. Hooke's work also inspired many people to perform experiments and conduct their own research in the field of natural philosophy. Samuel Pepys described it as, "The most ingenious book that ever I have read in my entire life" [6] and rushed to buy a set of microscopes in order to see what Hooke had seen. Because of its popularity and influence on the future directions of The Royal Society and science in general, it does not seem wrong to suggest that Micrographia, along with Newton's Principia Mathematica, are responsible for the establishment of empirical scientific research as a serious academic endeavor.

In his glowing letter to Hooke, Constanijn Huygens introduced an unknown amateur scientist to the Royal Society. The letter said, "I trust you will not be unpleased with the confirmation of so diligent a searcher as this man is." [7] This man was Antony van Leeuwenhoek, the future father of microbiology. Leeuwenhoek, pronounced "Lay-When-Hoke", apprenticed as a cloth merchant, and as an adult ran a drapery shop in the city of Delft, Netherlands. His interest in science, specifically microbiology, was a 
direct result of his study of Hooke's Micrographia, as well as his use of microscopes in the textile industry. While the Italian physician Marcello Malpighi concurrently described red blood cells, remarking on the presence of "a host of red atoms" [8] within the blood; it was not until the publication of Leeuwenhoek's observations by The Royal Society that the individual components of blood were described, such as their size or shape, with any amount of accuracy. Leeuwenhoek's correspondence with The Royal Society began in 1673 with a cordial, but academically serious, letter. The letter written in Dutch, as Leeuwenhoek did not speak English, Greek, or Latin, contained observations on mold, the eye and sting of a bee, and a louse, all made with his own microscopes. While Leeuwenhoek was observant and patient, it was the powerful microscopes with polished lenses he had crafted which allowed him to make such profound and detailed descriptions of blood cells, and their movement through capillaries.

Between the years 1674 and 1708 Leeuwenhoek wrote dozens of letters to the Royal Society. Three of these letters stand out as the most influential in describing blood cells and their movement.

The first letter spoke of the consistency, color, and presence of red blood cells within plasma.

"I have...endeavored to see and to know, what parts the Blood consists of; and at that length I have observed taking some Blood out of my own hand, that it consists of small round globuals driven through a Crystalline humidity or water; Yet whether all Blood be such, I doubt. And exhibiting my Blood to myself in very small parcels, the globuals yielded very little color." [9]

Building on his research, Leeuwenhoek wrote another letter to the Royal Society in 1675 detailing the texture and contents of his own blood.

"...I saw the plain globuals move within the waterish matter without any evaporation made; though there be but very few of them, and they appeared white where they lay together. And on this occasion I very well remember that about two years ago I observed my own blood, and noted, that those sanguineous globuals that make the blood red, seemed then to be firmer and harder than they are in my blood now; at which time my body was very much indisposed, so that I fell into a sickness...I am apt to imagine that those sanguineous globuals in a healthy body must be flexible and very pliant, if they shall pass through the small capillary veins and arteries..." [10]

Similar to his previous letter, this correspondence makes several profound observations. First, Leeuwenhoek comments on the changes in the blood's viscosity as a result of illness. Secondly, he describes the presence of "plain globuals... and they appeared white where they lay together." Being possibly the first documented observation of leukocytes. Finally, he postulates about the pliability and movement of the erythrocytes through capillaries, contemplating on their ability to move through vessels of various sizes.

Leeuwenhoek's third letter in 1709 focused on the circulation-specifically the movement of blood.

"I could perceive a great quantity of blood lying without the vessels... Now the blood being protruded out of the Heart in great quantities at once, and not being able to circulate with the same quickness thro' the small vessels, I suppose that the Tunica's or Coats of the exceeding small vessels are so extended, that the blood filtering thro' them, is found in great quantities without the guts... and is found in little lumps here and there without any order." [11]

Through the utilization of his previous observations, and the dissection of human tissues, Leeuwenhoek here presents one of the first examples of evidence-based medicine. By thinly slicing and analyzing a sample of intestinal tissue Leeuwenhoek had unknowingly become one of the first histologists, second only to Malpighi. And although his knowledge of human physiology was limited, his ability to theorize the role of blood during rapid muscle movement was based solely on his empirical observations. Leeuwenhoek continues his paper by further describing the movement of blood through the circulatory system; his initial observations laying the groundwork for years of physiological research he was to make through the use of microscopy, with almost all of his findings published by the Royal Society.

The compilation of these three letters, shaped by history and inspired by the Royal Society and its founding members, marked a paradigm shift in science and medicine. With the use of an emerging technology, the microscope, natural philosophers in the seventeenth century described the blood, its components and the circulation. Leeuwenhoek observed and documented how miniscule changes in the circulation were able to cause significant changes in tissues, organs, and organ systems. Like the experiments of Robert Hooke, Leeuwenhoek's conclusions were based on observations and evidence only. Though a revolutionary idea at the time, The Royal Society's philosophy of empiricism in science radically altered how experiments were conducted, and how conclusions were drawn. The creation of the Royal Society and the work of Antony van Leeuwenhoek marked a sea change in the development of science, and the contributions made by both cannot be understated. And while The Royal Society has made endless contributions to the advancement of science for the 
past 350 years, it is possible that their greatest and longest lasting contribution has been its charter, and the principles of observation and empiricism emphasized by its founders.

\section{References}

1. Pepys S (1923) In: Wheatley H (ed) The Diary of Samuel Pepys, vol 5. G. Bell and Sons, London, p 417

2. The Rebuilding Act of 1667 (2010) http://www.museumoflondon. org.uk/English/EventsExhibitions/Past/LondonsBurning/Themes/ 1405/1408/Page1.htm. Accessed 21 Aug 2010

3. Wren C (1965) Parentalia; or, memoirs of the family of the Wrens. Gregg, Farnborough, p 263

4. Wren C (1965) Parentalia; or, memoirs of the family of the Wrens. Gregg, Farnborough, p 195

5. Hooke R (1665) Preface to micrographia or some physiological descriptions of minute bodies made by magnifying glasses with observations and inquiries thereupon. http://www.roberthooke. org.uk/micro2.htm. Accessed 22 Aug 2010

6. Pepys S (1923) In: Wheatley H (ed) The Diary of Samuel Pepys, vol 4. G. Bell and Sons, London, p 338

7. Palm LC (1989) Leeuwenhoek and other Dutch correspondents of the Royal Society. Notes Rec R Soc Lond 43:191-207

8. Biography of Marcello Malpighi. http://www.encyclopedia.com/ doc/1G2-2830902791.html. Accessed 18 Sep 2010

9. Leeuwenhoek A (1674) More microscopical observations made by the same M. Leeuwenhoek and promised in numb. 97. of these tracts; communicated in his letters of August 15. 1673 and of April 7. 1674. Phil Trans 9:23-25

10. Leeuwenhoek A (1675) Other microscopical observations, made by the same, about the texture of the blood, the sap of some plants, the figure of sugar and salt, and the probable cause of the difference of their tastes. Phil Trans 10:380-385

11. Leeuwenhoek A (1709) Microscopical observations on the blood vessels and membranes of the intestines. In a letter to the Royal Society from Mr. Anthony van Leeuwenhoek, F.R.S. Phil Trans 26:53-58

\section{Additional Resources}

Tinniswood A (2001) His invention so fertile: a life of Christopher Wren. Oxford University Press, Oxford

Tinniswood A (2003) By permission of heaven: the story of the great fire of London. Jonathan Cape Ltd, London

Jardin L (2004) On a grander scale: the outstanding life and tumultuous times of Sir Christopher Wren. Harper Perennial, London

Jardin L (2003) The curious life of Robert Hooke: the man who measured London. Harper Perennial, London

Reddaway TF (1940) The rebuilding of London after the great fire. Jonathan Cape Ltd, London

Inwood S (2004) The forgotten genius: the biography of Robert Hooke 1635-1703. Macadam/Cage, London 